\title{
DEVELOPING STUDENTS' READING ACHIEVEMENT USING PORPE TECHNIQUE
}

\author{
By: \\ Nurhadiyanti \\ SMA Negeri 03 Unggulan Kayuagung \\ dhedhean92@gmail.com
}

\begin{abstract}
The purpose of this study was to examine the application of the PORPE technique in enhancing the eleventh-grade students' reading achievement of SMAN 3 Unggulan Kayuagung. Since there were five classes with 157 students, the samples were selected using purposive sampling. As a result, there were 62 students who took part as the sample. This study used a quasi-experimental design with nonrandomized pretest and posttest control groups. The data was gathered employing a written test, which was a multiple-choice reading test. The data was analyzed using the ttest. The results revealed that students who were taught through PORPE technique scored higher on reading tests. Besides, PORPE technique could improve the eleventh grade students' reading achievement of SMAN 3 Unggulan Kayuagung. Hence, students could understand the information form the text and were confidence in answering the questions.
\end{abstract}

Keywords: reading, students' reading achievement, PORPE technique

\section{INTRODUCTION}

Reading plays crucial part in

our life. Safitri and Zainil (2020)

stated that reading is a necessary skill

for English students since they must

be able to grasp the text given to them

by the teacher. Reading is a

psychological activity that needs the

reader to apply what he has learnt to

process the reading contents, rather than being a passive and mechanical

one (Zhao and Zhu, 2012). It implies

that reading is an active activity of searching for information that is carried out by an individual.

Although reading is essential part learned by the students, some of them still get difficulty in comprehending the text. As supported by Ullah and Fatema (2013), some 
students had less motivation in the dictionary. This activity makes the reading a text so that they only see at students read using much time so that glance and try to search the it made reading become displeasure. information in the exam without any Since there were many extensive or correct reading, as a problems faced by the students in result, their academic progress and reading, the teacher should find a their professional life were low. Due better technique to develop students' to the changing of the national reading achievement. One technique curriculum each period, the teacher of that could be applied in teaching English have problem to do reading was PORPE (Predict, adaptation so that the students have Organize, Rehearse, Practice, and less motivation to do reading Evaluate).

activities (Jing, 2013).

PORPE is a study technique Moreover, students faced that formalizes the cognitive learning problems in reading because they got process that successful readers use to difficulty understanding passages, comprehend information (Mortini and lack of vocabulary and motivation Jaya, 2019). According to Stahl (Sapitri, Novia, and Rachmanita (2014), PORPE works together to 2020). Hassan and Dweik (2021) develop students' thinking skills by explain that students were guiding them through the processes of unconfident to read English text. reading, studying, and learning They accustomed to finding the content. meaning by looking up the words in 
In addition, the steps of the PORPE method are to prepare students to guess a question, arrange or review fundamental concepts, practice or read aloud in front of the class, the exercise by responding to their predicted questions, and assess their assignment before directing it to the teacher (Setyorini et al., 2019).

Meanwhile, PORPE encourages students to integrate, evaluate, and comprehend about main topics by helping them recall them over time (Stahl, 2014).

\section{METHODOLOGY}

This study used a nonrandomized quasi-experimental design with pretest- post-test control groups.

The samples were taken using a purposive sampling method with some specifications, such as having an equal number of male and female students and being taught by the same English teacher. Consequently, flipping the coin was applied to determine the experimental and control groups. Therefore, the experimental group was chosen as XI IPA 2, whereas the control group was chosen as XI IPA 3. The data was provided by asking reading test questions in multiple-choice format. The t-test was used to assess the data.

\section{RESULTS AND DISCUSSION}

The mean pretest score in the experimental group was 81.09 , with the highest student score of 84 and the lowest score of 60 . The mean score on the posttest was 87.27 , with the highest score of 96 and the lowest score of 68 .

Moreover, the pretest mean score in the control group was 64.73 , with the highest score of 84 and the 
lowest score of 40 . The mean score in the posttest was 72.73 , with the highest score of 88 and the lowest score of 44 .

Based on the calculation done by using independent samples t-test, the mean posttest score in the experimental group was 87.15 with a standard deviation of 6.83 , while the mean posttest score in the control group was 72.73 with a standard deviation of 10.79 .

Furthermore, in two tailed testing with $\mathrm{df}=64$, the mean difference between the two groups was 14.42 at the significant level of $\mathrm{p}<0.05$, t-obtained was 6.48 , and the critical value of t-table was 1.99 . The null hypothesis (Ho) was rejected, and the alternative hypothesis (Ha) was accepted because t-obtained (6.48) was higher than t-table (1.99) and $\mathrm{p}_{\text {value }}(0.00)$ was lower than $\alpha_{\text {value }}$
(0.05). In other words, PORPE technique could students' reading achievement of SMA Negeri 3 Unggulan Kayuagung.

PORPE technique could encourage students' reading comprehension. Besides, students followed the steps using PORPE technique so that they understand the point in the reading texts. As a result, they had ability to respond the questions easily. PORPE technique forced students to be active readers. The students were able to use their long-term memory to identify and place the main points, examples, and organization of the texts through the PORPE technique, resulting in their confidence in answering the questions.

PORPE technique had helped the eleventh grade students' reading achievement of SMAN 3 Unggulan 
Kayuagung. This result was in line with research conducted by Saiful, Jabu, and Atmowardoyo (2019) that stated PORPE made a great deal of sense at an intuitive level. It incorporated attention to metacognitive development, content mastery, effective predicting, organizing, and test writing. Structurally, it progressed in logical movements from teacher instruction, modeling, and guidance, to total students independence and controlled the purpose of all study skills instruction.

The students learned reading using PORPE technique had high desire in learning reading so that they could know the content of the reading text and had progress in their reading achievement. The students in the experimental group also gave good response during the treatment.
Through PORPE, students could determine and organize the main topic. Then, they practiced recalling information by writing individually. Students engaged in observation and a checklist to assess the accuracy, correctness, and connection of their comments.

Moreover, PORPE could be given both individual and group so that they could work together with their teams. Therefore, the students communicated freely and could cooperate effectively on their each member of group. They could obtain more key ideas of the texts with completeness, accuracy, and appropriateness evaluation. The students who were active and passive could share their thought together.

During applying PORPE technique, the students had high discipline because they obey the rule 
so that they could reply the questions. Certainly, it made them accustomed to doing the task. However, students who were in control group that used explanation method could not be active and discipline in learning process because did not have the procedures to be guided. Thus, they did not develop considerably in their reading abilities.

\section{CONCLUSION}

The PORPE technique significantly improves students' reading comprehension. The experimental group's pupils found that using the PORPE technique made it easier and more effective to comprehend reading materials and respond to questions. They could practice understanding passages to acquire basic thoughts concerning the answers they are required to learn.
They could also grasp the main pattern of the paragraphs. Thus, they were confident in their ability to respond to the question.

\section{REFERENCES}

Hassan, I. J., \& Dweik, B. S. (2021). Factors and challenges in English reading comprehension among young Arab EFL Learners. Academic Research International, 12(March), 18-30. Jing, J. (2013). Teaching English reading through MI theory in primary schools. English Language Teaching, 6(1), 132140. https://doi.org/10.5539/elt.v6n1p 132

Mortini, V. A., \& Jaya, A. (2019). The effectiveness of PORPE strategy in teaching reading comprehension to the eleventh 
grade students of SMA Yayasan

Bakti Prabumulih. Esteem:

Journal of English Study

Programme, 2(2), 160-167.

Novia, F. (2017). Using Bamboo

Dancing Method to improve

reading skill. Language and

Education Journal, 2(1).

http://ejournal.uniski.ac.id/index.

php/LEJ/article/view/55

Safitri, N., \& Zainil, Y. (2020).

Students' difficulties in

comprehending hortatory

exposition text at SMAN 1

Luhak Nan Duo Pasaman Barat.

Journal of English Language

Teaching, 9(4), 750-758.

https://doi.org/10.24036/jelt.v9i4

.110559

Saiful, Jabu, B., \& Atmowardoyo, H.

(2019). The effects of the

PORPE method on students'

reading comprehension and metacognitive awareness.

Journal of Language Teaching

and Research, 10(3), 569-582.

https://doi.org/10.17507/jltr.100

Sapitri, D., Novia, F., \& Rachmanita. (2020). An analysis of students' difficulties in comprehending narrative text. Language and Education Journal, 5(2), 103-

112.

Setyorini, Y., Juniardi, Y., \& Rima,

R. (2019). The Influence of

Using Predict, Organize,

Rehearse, Practice, Evaluate

(PORPE) Method toward

Students' Reading

Comprehension. ELITE

JOURNAL : Journal of English

Linguistics, Literature, and

Education, 2(1), 2019.

www.journal.elitenglish.org

Stahl, N. A. (2014). Porpe: A 
Nurhadiyanti

comprehensive study strategy

utilizing self-assigned writing.

Journal of College Reading and

Learning, 20(1), 51-57.

https://doi.org/10.1080/1079019

5.1987 .10849898

Ullah, M. M., \& Fatema, S. (2013).

Why some students are less

motivated in reading classes at

Tertiary Level in Bangladesh.

English Language Teaching, 6(5), 129-140.

https://doi.org/10.5539/elt.v6n5p

129

Zhao, X., \& Zhu, L. (2012). Schema

theory and college English

reading teaching. English

Language Teaching, 5(11), 111-

117.

https://doi.org/10.5539/elt.v5n11

p111 